DOI: $10.19195 / 2084-5065.46 .2$

\title{
Uwagi na temat charakteru prawnego dyrektywy wymiaru kary za ciąg przestępstw. Część II
}

\author{
RAJNHARDT KOKOT \\ Katedra Prawa Karnego Materialnego \\ Wydział Prawa, Administracji i Ekonomii Uniwersytetu Wrocławskiego
}

Przyjęcie w pierwszej części niniejszego opracowania ${ }^{1}$ stanowiska zakładającego, iż ciąg przestępstw jest jedną z ustawowych przesłanek nadzwyczajnego obostrzenia kary, aktualizuje problematyczną na gruncie doktryny kwestię interpretacji możliwych przypadków zbiegu podstaw nadzwyczajnego wymiaru kary — tak kolizyjnych, jak jednokierunkowych. W kontekście wielości zachowań objętych konstrukcją ciągu przestępstw może powstać wątpliwość dotycząca zwłaszcza zbiegu podstaw nadzwyczajnego obostrzenia i nadzwyczajnego złagodzenia kary (art. 57 $\S 2$ k.k.). Rodzi się mianowicie pytanie, czy aplikacja tego przepisu jest uprawniona, gdy podstawy nadzwyczajnego złagodzenia kary zachodzą w odniesieniu do niektórych tylko przestępstw składających się na ciąg, czy choćby co do jednego tylko z nich, czy też można go stosować dopiero wówczas, gdy odnoszą się one do każdego z przestępstw objętych regulacją art. $91 \S 1$ k.k. Zdania na ten temat są podzielone. Wstępnie wykluczyć należy możliwość „rozbicia” ciągu przestępstw na dwa cią-

${ }^{1}$ R. Kokot, Uwagi na temat charakteru prawnego dyrektywy wymiaru kary za ciag przestępstw. Część I, „Nowa Kodyfikacja Prawa Karnego” 2016, nr 41, s. 33-53.

Nowa Kodyfikacja Prawa Karnego 46, 2017

(C) for this edition by CNS 
gi, z których jeden obejmowałby przestępstwa, co do których zachodzi przesłanka nadzwyczajnego złagodzenia kary, drugi natomiast te, których taka przesłanka nie dotyczy. Zważywszy, iż konstrukcja z art. $91 \S 1$ k.k. jest instytucją prawa karnego materialnego, sąd zobowiązany jest do traktowania przestępstw wchodzących w skład ciągu jako niepodzielnej całości. Ponadto procedura ta, wbrew ustawie, prowadziłaby do wymiaru kary łącznej w oparciu o kary jednostkowe za dwa ciągi tam, gdzie ma być przecież wymierzona jedna kara za wszystkie przestępstwa tworzące jeden ciąg.

Sąd Najwyższy — odmiennie niż w przypadku czynu ciągłego ${ }^{2}$ wyraził liberalny pogląd, iż niezależnie od tego, czy przesłanki uzasadniające redukcję dolegliwości karnej dotyczą wszystkich, czy też jedynie niektórych przestępstw tworzących ciąg, możliwość wyboru w warunkach art. 57 § 2 k.k. nadzwyczajnego złagodzenia jest dopuszczalna ${ }^{3}$. W piśmiennictwie, nie bez racji, kwestionuje się ten kierunek wykładni. Skoro bowiem ciąg przestępstw to forma ich zbiegu, w którym każdy czyn traktowany jest jako zachowanie autonomiczne, to uprawnienie do złagodzenia odpowiedzialności karnej za ów zbiór może być wyprowadzane tylko wówczas, gdy jej podstawa dotyczy każdego z przestępstw $\mathrm{z}_{\text {osobna }}{ }^{4}$, analogicznie jak w przypadku realnego zbiegu przestępstw -

${ }^{2}$ Uchwała SN z 29 października 2002 r., I KZP 30/02, OSNKW 2002, nr 11-12, poz. 89 . W judykacie tym Sąd Najwyższy przyjął, iż nadzwyczajne złagodzenie kary za czyn ciągły możliwe jest tylko wówczas, gdy podstawa redukcji odpowiedzialności (w rozstrzyganej sprawie wynikająca z art. 60 § 3 k.k.) dotyczy każdego z zachowań składających się na tę konstrukcję.

3 Uchwała SN z 19 sierpnia 1999 r., I KZP 24/99, OSNKW 1999, nr 9-10, poz. 48. Por. aprobujące glosy: A. Zoll, „Orzecznictwo Sądów Polskich” 2000, nr 2, s. 90-91; A. Michalska-Warias, „Prokuratura i Prawo” 2000, nr 4, s. 105 n.; M. Kulik, Glosa do uchwaty SN z 19 sierpnia 1999 r., I KZP 24/99, „Przegląd Sądowy” 2000, nr 2, s. 140 n.; także R.A. Stefański, Przegląd uchwał Izby Karnej i Wojskowej Sądu Najwyższego w zakresie prawa karnego materialnego, prawa karnego wykonawczego i prawa wykroczeń za 1999 r., „Wojskowy Przegląd Prawniczy” 2000, nr 1, s. 71-73; postanowienie SN z 19 marca 2003 r., V KK 188/02, Legalis; wyrok SA w Lublinie z 5 października 2004 r., II AKa 252/04, „Prokuratura i Prawo” 2005, nr 7-8, poz. 22; postanowienie SN z 4 lutego 2008 r., III KK 363/07, OSNKW 2008, nr 4, poz. 28 wraz z aprobującą glosą A. Michalskiej-Warias, Legalis.

${ }^{4}$ Por. J. Majewski, Glosa do uchwaty SN z 19 sierpnia 1999 r., I KZP 24/99, „Orzecznictwo Sądów Polskich” 2000, nr 5, s. 241 n.; A. Rybak, Glosa do uchwaty SN

Nowa Kodyfikacja Prawa Karnego 46, 2017

(C) for this edition by CNS 
którego ciąg jest wszakże jednorodną odmianą, a w którym możliwość nadzwyczajnego złagodzenia kary dotyczy tylko tych przestępstw, do których odnoszą się okoliczności redukujące karę. W tym kontekście odmienny pogląd na dopuszczalność nadzwyczajnego złagodzenia kary za ciąg zaprzeczałby powszechnie akceptowanemu w literaturze spojrzeniu na prawną naturę tej instytucji i jej normatywnemu powinowactwu. Jako niezasadne, a nawet nielogiczne jawi się więc dopuszczenie samej możliwości nadzwyczajnego złagodzenia, jeśli przesłanka jego stosowania odnosiłaby się do jednego tylko z ogniw łańcucha przestępstw. O ile jeszcze w przypadku ciągu składającego się z mniejszej liczby przestępstw, zwłaszcza dwóch, zaistnienie podstawy nadzwyczajnego złagodzenia tylko co do jednego z nich nie tworzyłoby tak silnego wrażenia braku uzasadnienia, a tym samym nieusprawiedliwionej możliwości łagodzenia kary, i to w sposób nadzwyczajny, o tyle jednak im większa dysproporcja między liczbą przestępstw, co do których przesłanki nadzwyczajnego złagodzenia kary zachodzą, a liczbą przestępstw, w odniesieniu do których one nie występują, tym silniejsze wrażenie nieracjonalności stanowiska dopuszczającego nadzwyczajne złagodzenie kary za cały ciąg. Jak słusznie wskazuje się w literaturze, stanowisko przyjęte przez Sąd Najwyższy prowadzić może do paradoksalnej, a z kryminalnopolitycznego punktu widzenia całkowicie niedorzecznej sytuacji, w której opłacalne staje się popełnienie większej liczby przestępstw, z których choć co do jednego zachodzą podstawy nadzwyczajnego złagodzenia. Idąc tym tropem, na-

z 19 sierpnia 1999 r., I KZP 24/99, „Państwo i Prawo” 2000, nr 6, s. 99-106; K. Daszkiewicz, Kary za przestepstwa ciagłe i ciagi przestęstw, „Prokuratura i Prawo” 2000, nr 5, s. 27-28; P. Kardas, [w:] Kodeks karny. Część ogólna. Komentarz, red. A. Zoll, t. 1, Warszawa 2007, s. 1028; W. Wróbel, [w:] Kodeks karny. Część ogólna. Komentarz, red. A. Zoll..., s. 722; S. Żółtek, [w:] Kodeks karny. Część ogólna, red. M. Królikowski, R. Zawłocki, t. 2, Warszawa 2011, s. 790; J. Raglewski, Glosa do postanowienia SN z 4 lutego 2008 r., III KK 363/07, OSNKW 2008, nr 4, poz. 28. Stanowisko takie wyrażane było także w judykaturze. Tak np. wyrok SA w Krakowie z 18 lipca 2002 r., II AKa 166/02, KZS 2002, nr 9, poz. 10. Taki też pogląd wyraża P. Kardas, już po nowelizacji kodeksu karnego z 20 lutego 2015 r. przyjmując, iż nadzwyczajne złagodzenie jest możliwe tylko wówczas, gdy w stosunku do każdego przestępstwa stanowiącego element ciągu aktualizuje się możliwość nadzwyczajnego złagodzenia kary. Analizuje to w oparciu o zbieg różnych postaci zjawiskowych, z których jedną jest pomocnictwo stanowiące autonomiczną podstawę nadzwyczajnego złagodzenia — P. Kardas, [w:] Nowelizacja prawa karnego. Komentarz, red. W. Wróbel, Kraków 2015, s. 660.

Nowa Kodyfikacja Prawa Karnego 46, 2017

(C) for this edition by CNS 
leżałoby bowiem przyjmować, iż brak jest podstaw do nadzwyczajnego złagodzenia kary, gdy sprawca dopuścił się jednego przestępstwa poza okolicznościami uzasadniającymi sięgnięcie po nadzwyczajną redukcję odpowiedzialności, możliwość jego premiowania łagodniejszą karą pojawiałaby się zaś wraz z popełnieniem kolejnego, czy nawet kolejnych przestępstw, z których choćby jedno tylko było zrealizowane w warunkach uprawniających do zejścia poniżej dolnego progu ustawowego zagrożenia karą ${ }^{5}$. Rozumowanie to ma więc w istocie charakter kryminogenny, zachęcając jednorazowego sprawcę czynu zabronionego do popełniania następnych przestępstw w taktycznie kreowanych okolicznościach uzasadniających nadzwyczajne złagodzenie. W takim przypadku ciąg przestępstw stawałby się więc swoistą okolicznością łagodzącą odpowiedzialność karną, zaprzeczając swojej ustawowej naturze i funkcjí. Rzecz jasna, nie można nie zauważyć, że obawy te zmniejsza w pewnym stopniu nieznająca wyjątku zasada fakultatywności stosowania nadzwyczajnego złagodzenia. To bowiem w przypadku zaistnienia kolizyjnego zbiegu podstaw nadzwyczajnego wymiaru kary z art. $57 \S 2$ k.k., przy zastosowaniu tzw. „mocnej” interpretacji tego przepisu, zawsze ma charakter uznaniowy, choćby nawet, występując poza tym zbiegiem, miało charakter bezwzględny, jak np. w przypadku art. 60 § 3 k.k. Regulacja art. $57 \S 2$ k.k., według stanowiska judykatury oraz większościowego poglądu wyrażanego w literaturze, przekształca bowiem obligatoryjne przesłanki modyfikacji odpowiedzialności karnej, niezależnie od ich kierunku, w podstawy fakultatywne, dając sądowi możliwość wyboru ograniczoną jedynie wskazaniami dyrektyw sądowego wymiaru kary ${ }^{7}$.

5 Np. popełnienie w ramach ciągu kilku przestępstw — dokonanych i usiłowanych — i jednego w formie usiłowania nieudolnego lub dopuszczenie się w ciągu kilku sprawstw, które zamyka jednokrotne pomocnictwo.

6 Por. K. Daszkiewicz, op. cit., s. 28; J. Majewski, op. cit., s. 241 n.; wyrok SA w Krakowie z 18 lipca 2002 r., II AKa 166/02, KZS 2002, nr 9, poz. 10.

7 W piśmiennictwie obecny jest jednak także nurt tzw. ,słabej” interpretacji art. 57 $\S 2$ k.k. Tak np. A. Rybak, op. cit., s. 105-106; M. Kulik, op. cit.; A. Michalska-Warias, Glosa do postanowienia SN z 4 lutego 2008 r., III KK 363/07, OSNKW 2008, nr 4, poz. 28, Legalis. W myśl tego kierunku wykładni kolizja obligatoryjnej i fakultatywnej podstawy nadzwyczajnego wymiaru kary prowadzi do konieczności zastosowania przesłanki obligatoryjnej. Zatem w razie zbiegu podstaw nadzwyczajnego obostrzenia z art. $91 \S 1$ k.k. oraz obligatoryjnej podstawy nadzwyczajnego złagodzenia z art. 60 § 3 k.k. istnieje

Nowa Kodyfikacja Prawa Karnego 46, 2017

(C) for this edition by CNS 
Trafnie też zauważa J. Majewski, odwołując się do konstytucyjnej zasady równości wobec prawa, iż przyjęcie możliwości nadzwyczajnego złagodzenia kary, gdy choćby tylko co do jednego z przestępstw pozostających w ciągu zachodziła podstawa redukcji karania, może prowadzić do nieuprawnionego różnicowania sytuacji prawnej sprawcy w zależności od tego, czy popełnione przez niego w warunkach ciągu przestępstwa stanowiłyby przedmiot jednego postępowania sądowego, co stanowi regułę, czy też rozpatrywane byłyby w ramach odrębnych postępowań (art. 91 $\S 3$ k.k. $)^{8}$. W ostateczności więc, wobec zarysowanych wątpliwości wykładniczych, pozostaje mieć nadzieję, iż uwzględnienie przez orzekający w sprawie sąd, w jednostkowym wymiarze kary nadzwyczajnie zmodyfikowanej, dyrektyw sądowego wymiaru kary, tak ogólnych z art. 53 $\S 1$ k.k., jak szczególnych odnoszących się do sprawcy lub rodzaju kary, zapobiegnie werdyktom jedynie formalnie uprawnionym, a merytorycznie nieuzasadnionym.

Na tle kolizyjnego zbiegu podstaw nadzwyczajnego wymiaru kary $\mathrm{z}$ udziałem reguły wymiaru kary za ciąg przestępstw jako zagadnienie znacznie mniej kontrowersyjne jawi się kwestia zbiegu nadzwyczajnego obostrzenia z art. $91 \S 1$ k.k. z inną podstawą nadzwyczajnej progresji karania. Nie ulega wątpliwości, iż tak jak w każdym innym przypadku zbiegu podstaw o tym samym wektorze, nie wchodzi w grę ich kumulatywne stosowanie, a więc dwu- lub wielokrotne, ,piętrowe” nadzwyczajne obostrzenie kary. Teza ta nie stoi wszakże na przeszkodzie, by w wytyczaniu ustawowych granic nadzwyczajnego wymiaru kary uwzględniać te okoliczności łącznie. Trudny do zaakceptowania jest pogląd, który możliwość takiego zbiegu ex definitione wyklucza, przyjmując w każdej sytuacji - niezależnie od tego, czy inna podstawa nadzwyczajnego obostrzenia odnosi się do niektórych tylko czy też do wszystkich przestępstw pozostających w ciągu - prymat i zarazem wyłączność stosowania reguły

konieczność, za sprawą ratio legis regulacji art. 60 § 3 k.k., nadzwyczajnego złagodzenia z wyłączeniem możliwości nadzwyczajnego obostrzenia na podstawie art. $91 \S 1$ k.k. Art. $60 \S 3$ k.k. w tym układzie należałoby więc traktować jako swoiste lex specialis w stosunku do art. $57 \S 2$ k.k. Tylko bowiem taka interpretacja, choć powodować to może znaczne uprzywilejowanie sprawcy, miałaby zachować funkcję, jaką ustawodawca przypisał regulacji art. $60 \S 3$ k.k.

8 J. Majewski, op. cit., s. 241 n.

Nowa Kodyfikacja Prawa Karnego 46, 2017

(C) for this edition by CNS 
obostrzenia wynikającej z art. $91 \S 1$ k.k. ${ }^{9}$ Uwzględnienie tych podstaw „łącznie” nie oznacza bynajmniej jedynie łącznego uwzględnienia ich w jednostkowym, sądowym wymiarze konkretnej kary jako okoliczności obciążającej, ale także łączne kształtowanie zmodyfikowanych granic odpowiedzialności karnej, jeśli między regułą wymiaru kary z art. 91 § 1 k.k. a inną przesłanką nadzwyczajnego obostrzenia zachodzą w tym zakresie różnice. Jeżeli więc wobec faktu, iż ciąg przestępstw reformuje jedynie górną granicę odpowiedzialności, zwiększając ją o połowę, pozostająca z nim w zbiegu inna przesłanka nadzwyczajnego obostrzenia wymusza podniesienie dolnej granicy lub ogranicza możliwość wymiaru kary łagodniejszego rodzaju, łączne stosowanie tych podstaw prowadziłoby do modyfikacji zarówno górnej, jak i dolnej granicy odpowiedzialności, de facto na poziomie dolnym — zważywszy na obligatoryjny charakter tej zmiany — zawężając przestrzeń wymiaru kary, wyłączając jednocześnie możliwość wymierzenia kary łagodniejszego rodzaju. Sytuacja taka występowałaby np. w przypadku ciągu przestępstw popełnionych w warunkach recydywy wielokrotnej z art. $64 \S 2$ k.k. lub jednej z okoliczności wskazanych w art. 65 k.k., czy też ciągu zachowań w warunkach art. 178 k.k. Ważne jest przy tym to, iż przyjęcie takiego zbiegu możliwe jest tylko w tym przypadku, gdy wszystkie przestępstwa tworzące ciąg są jednocześnie przestępstwami powrotnymi, względnie objętymi regulacją art. 65 k.k. lub art. 178 k.k. ${ }^{10}$ Wynika to z wymogu tożsamej kwalifika-

9 S. Żółtek, op. cit., s. 791-792.

10 Por. wyrok SA w Katowicach z 30 października 2008 r., II AKa 266/08, „Prokuratura i Prawo" 2009, nr 6, poz. 42. Jak wprost wynika z tezy przytoczonego orzeczenia: „Art. $91 \S 1$ k.k. przewiduje warunek identyczności podstawy kwalifikacji prawnej w odniesieniu do każdego przestępstwa składającego się na ciąg, co bezwzględnie musi oznaczać, że podstawę ciągu mogą stanowić jedynie zachowania, z których każde wyczerpuje identycznie określony zestaw znamion typu czynu zabronionego oraz które mają jednorodną stronę podmiotową i identycznie określone ustawowe granice kary. [...] Art. $65 \S 1$ k.k. wskazuje na możliwość przyjęcia dodatkowych znamion modyfikujących przestępstwa stypizowane w części szczególnej kodeksu karnego lub innych ustawach karnych. Jednym z tych znamion modyfikujących jest uczynienie z popełniania przestępstw stałego źródła dochodu. Przyjęcie, iż sprawca czynów zabronionych uczynił sobie z ich popełniania stałe źródło dochodu, w sposób oczywisty rozszerza ustawowy zestaw znamion czynu zabronionego, obliguje Sąd do ujęcia w kwalifikacji prawnej takiego czynu przepisu art. $65 \S 1$ k.k., co w konsekwencji wpływa na wymiar kary, modyfikując obligatoryjnie dolny próg ustawowego zagrożenia. W efekcie ob-

Nowa Kodyfikacja Prawa Karnego 46, 2017

(C) for this edition by CNS 
cji prawnej przestępstw tworzących ciąg, co powszechnie przyjmowano w literaturze przed nowelizacją z 20 lutego 2015 r., czy też tożsamości podstawy wymiaru kary, czego wymaga ustawa karna po wspomnianej zmianie. Wymienione podstawy nadzwyczajnego obostrzenia muszą się zaś znaleźć zarówno w kwalifikacji prawnej, jak i w podstawie wymiaru kary, w tym ostatnim przypadku łącznie z art. 91 § 1 k.k.

W ogólniejszym kontekście poglądu przyjmującego, iż ciąg przestępstw stanowi jedną z podstaw nadzwyczajnego obostrzenia kary, aktualizuje się też pytanie, dlaczego instytucja czynu ciągłego z art. 12 k.k., wywodząca się wszakże z tej samej konstrukcji normatywnej — przestępstwa ciągłego w rozumieniu art. 58 k.k. z 1969 r. stanowiącego wówczas jednolitą podstawę nadzwyczajnej progresji karania - nie spotyka się $\mathrm{z}$ analogicznymi skutkami w sferze wymiaru kary. W literaturze jeszcze przed wejściem w życie kodeksu karnego z 1997 r. zarysował się spór o zasadność takiej dyferencjacji. Warto wspomnieć, iż próby odejścia od przyjętego w obowiązującej ustawie dualizmu — nie tylko zresztą w sferze wymiaru kary, ale także samej konstrukcji prawnej — były podejmowane także na poziomie legislacyjnym ${ }^{11}$. Pogląd akceptujący

jęcie jednym ciągiem przestępstw, które zostały popełnione w warunkach art. $65 \S 1$ k.k., i przestępstw, które nie zawierają żadnego ze znamion modyfikujących z art. 65 $\S 1$ k.k., skutkuje, iż nie można utworzyć przy wykorzystaniu art. $91 \S 1$ k.k. nowej, jednej i wspólnej dla wszystkich przestępstw pozostających w ciągu dyrektywy nakazującej sądowi wymierzyć za ciąg przestępstw jednej kary, której dolna granica będzie taka sama”. W konsekwencji, jak przyjęto w wyroku: „Nie jest więc prawidłowe kwalifikowanie jako ciągu przestępstw zachowań różnie sankcjonowanych, choćby podobnych przedmiotowo. Nie można bowiem oznaczyć jednej kary za wszystkie przestępstwa, gdy są one zagrożone karami różnej wysokości, choćby na skutek przyjęcia pewnych okoliczności tkwiących w ustaleniach faktycznych, takich jak przykładowo znamiona modyfikujące $\mathrm{z}$ art. $65 \S 1$ k.k. lub działanie w warunkach powrotu do przestępstwa $\mathrm{z}$ art. 64 § 2 k.k.”

11 Projekt prezydencki nowelizacji kodeksu karnego z 20 grudnia 2001 r. (druk sejmowy nr 181) przewidywał skreślenie art. 91 k.k. i wprowadzenie w zmienionym art. 12 nowej formuły jednolitego przestępstwa ciągłego ustawowo określonego. W proponowanej wersji przepis ten brzmiał: „Odpowiada za przestępstwo ciągłe ten, kto dopuszcza się dwu lub więcej jednorodnych czynów, podjętych w krótkich odstępach czasu w wykonaniu tego samego zamiaru lub z wykorzystaniem takiej samej sposobności”. Pojęcie przestępstwa ciągłego stałoby się tym samym nie tylko pojęciem prawnym, jakim zresztą było również pod rządami kodeksu karnego z 1969 r., ale także pojęciem mającym swą legalną definicję, ustawowo zdefiniowanym. Konsekwencje tak ujętego przestępstwa ciągłego określał art. 56a projektu. Wynikało z niego, iż: „W razie skazania za przestęp-

Nowa Kodyfikacja Prawa Karnego 46, 2017

(C) for this edition by CNS 
rozwiązanie kodeksowe uzasadniany jest na kilka sposobów. Pierwszy z nich odwołuje się do argumentu przywoływanego jeszcze pod rządami kodeksu karnego z 1969 r., iż niedopuszczalne jest dwukrotne zaliczanie tej samej okoliczności, jaką jest powtarzalność zachowania w ramach i warunkach jednego przestępstwa ciągłego, jako podstawy przejścia na typ kwalifikowany (np. w związku ze znaczną wartością zabranego mienia), a następnie dodatkowo jako podstawy nadzwyczajnego obostrzenia

stwo ciągłe sąd może orzec karę w granicach do najwyższego ustawowego zagrożenia zwiększonego o połowę". Rozwiązanie to spotkało się z życzliwym przyjęciem części doktryny, zwracającej uwagę na nieuzasadnione różnicowanie skutków czynu ciągłego i ciągu przestępstw. Por. np. J. Warylewski, Prawo karne. Część ogólna, Warszawa 2012, s. 388. Zniknąć tym samym miało bowiem nieuprawnione ani aksjologicznie, ani kryminalnopolitycznie uprzywilejowanie sytuacji prawnej sprawcy czynu ciągłego na tle sprawcy ciągu przestępstw, za który przewidziane było nadzwyczajne obostrzenie kary. W swej istocie analogiczne uzasadnienie dla surowszego karania za czyn ciągły (wyższy stopień społecznej szkodliwości i winy) nie było bowiem de lege lata przez ustawę uwzględniane. W analogicznym kierunku zmierzały zmiany zaproponowane w tym czasie także w projekcie obywatelskim (druk sejmowy nr 775 z 11 lipca 2002 r.), który pod pojęciem przestępstwa ciągłego rozumiał ,dwa lub więcej zachowań podjęte w stosunkowo krótkich odstępach czasu ze z góry podjętym zamiarem lub wykorzystaniem tej samej trwałej sposobności i skierowane przeciwko takiemu samemu dobru prawnemu" (art. $113 \S 3$ projektu). Art. 63 tego projektu przewidywał następstwo przestępstwa ciągłego w postaci możliwości wymierzenia kary do podwójnego ustawowego zagrożenia, nie przekraczając jednak górnej granicy danego rodzaju kary. Postulat usunięcia dualizmu obecnego w kodeksie karnym z 1997 r. zawierał także projekt kodeksu karnego z 18 maja 2007 r. (druk sejmowy nr 1756). Usuwał on art. 91 k.k., modyfikując jednocześnie art. 12 k.k. Brzmieniem nawiązywał do poprzedniego projektu, różniąc się od niego jedynie detalami: „Odpowiada za przestępstwo ciągłe ten, kto dopuszcza się dwóch lub więcej czynów skierowanych przeciwko takiemu samemu dobru, podjętych w krótkich odstępach czasu, w wykonaniu z góry powziętego zamiaru lub z wykorzystaniem takiej samej trwałej sposobności". Jak wynikało z uzasadnienia tego projektu, zmiana ta miała usunąć „słabe strony czynu ciągłego oraz ciągu przestępstw”, rozszerzając możliwość stosowania tej instytucji w porównaniu do stanu obowiązującego i rozciągając ją na przestępstwa nieumyślne oraz zachowania podejmowane w tzw. zamiarze odnawianym (sukcesywnym) pod wpływem trwałej sposobności do popełnienia określonego przestępstwa. Art. 56 projektu, podobnie jak poprzednia propozycja legislacyjna, określał surowe następstwa w zakresie wymiaru kary, stanowiąc, iż: „W razie skazania za przestępstwo ciągłe, sąd może orzec karę w granicach do podwójnej górnej granicy ustawowego zagrożenia, nie przekraczając jednak granicy danego rodzaju kary".

Nowa Kodyfikacja Prawa Karnego 46, 2017

(c) for this edition by CNS 
kary $^{12}$. Dodać należy, iż motywacja taka aktualizuje się, na zasadzie analogii, także w przypadku sekwencji „,zachowań” niestanowiących z osobna przestępstw, a jedynie wykroczenia lub czyny o znikomym stopniu społecznej szkodliwości. Uwzględnienie ciągłości jako podstawy przestępności wynikającej z sumowania oceny poszczególnych nieprzestępnych zachowań wraz z możliwością nadzwyczajnego obostrzenia kary za to „sumaryczne przestępstwo" stanowiłoby bowiem dublowanie tej samej przesłanki wpływającej na charakter i zakres odpowiedzialności karnej. Rezygnację z możliwości nadzwyczajnego obostrzenia kary w stosunku do czynu ciągłego uzasadnia się także jego podobieństwem do kategorii tzw. przestępstw zbiorowych charakteryzujących w ustawowym opisie czynność wykonawczą jako wielokrotną, powtarzalną lub wieloodmianową. Racjonalizując stanowisko ustawodawcy przyjęte odnośnie do karalności czynu ciągłego, pogląd ten wskazuje, iż skoro w odniesieniu do sprawcy tych zachowań brak możliwości nadzwyczajnej progresji karania - wymiar kary następuje bowiem w granicach zwyczajnego wymiaru kary (ustawowego zagrożenia) określonego w sankcji przestępstw zbiorowych — to i w odniesieniu do art. 12 k.k., na zasadzie analogii, uzasadnione jest pominięcie możliwości nadzwyczajnego obostrzenia, brak bowiem powodów do różnicowania tych przypadków i surowszego traktowania sprawcy czynu ciągłego ${ }^{13}$. W kontekście przyjętego w obowiązującym kodeksie rozróżnienia przytoczyć należałoby także pogląd wyrażony przez M. Cieślaka, który jeszcze pod rządami kodeksu z 1969 r. kontestował zasadę i celowość nadzwyczajnego obostrzenia kary za przestępstwo ciągłe. Krytycznie oceniając obowiązujący wówczas model wymiaru kary, formułował wprost wątpliwość, dlaczego „ten, kto wykonał zamierzony czyn ratami, ma być (a przynajmniej może być) ukarany z 50-procentową podwyżką kary w stosunku do sprawcy, który uczynił to za jednym

12 Por. K. Buchała, Prawo karne materialne, Warszawa 1989, s. 430; I. Andrejew, Polskie prawo karne w zarysie, Warszawa 1976, s. 241; wyrok SN z 22 listopada 1975 r., IV KR 215/75, OSNKW 1976, nr 2, poz. 26; wyrok SN z 12 marca 1975 r., V KR 371/74, OSNPG 1975, nr 11, poz. 117; wyrok SN z 8 lipca 1977 r., IV KR 125/77, OSNPG 1977, nr 11, poz. 100 .

13 M. Dąbrowska-Kardas, P. Kardas, Czyn ciagty i ciag przestepstw $w$ kodeksie karnym z 1997 r., [w:] Nowa kodyfikacja karna. Kodeks karny. Krótkie komentarze, Warszawa 1998, s. 79.

Nowa Kodyfikacja Prawa Karnego 46, 2017

(C) for this edition by CNS 
zamachem"14. Zarzut ten, niewątpliwie ogólniejszej natury, w obecnym stanie prawnym mógłby więc wyznaczać kolejny kierunek uzasadniania stanowiska ustawodawcy co do wymiaru kary za czyn ciągły. Zwrócić należy wreszcie uwagę, iż pogląd o potrzebie łagodniejszego traktowania sprawcy przestępstwa ciągłego uderzający w przewidzianą w art. 58 k.k. z 1969 r. możliwość nadzwyczajnego obostrzenia kary — a z obecnej perspektywy mogący racjonalizować brak reguły nadzwyczajnego wymiaru kary w art. 12 k.k. — uzasadniany był w literaturze także szczególną treścią strony podmiotowej. Zdaniem A. Sadowskiego argumentem za łagodniejszym traktowaniem sprawcy przestępstwa ciągłego miałby być mianowicie niższy stopień winy sprawcy kilku pozostających w związku czynów. Skoro bowiem wynikały one z jednego impulsu woli, „dokonanie jednego aktu w warunkach sprzyjających stępia niewątpliwie wrażliwość moralną przestępcy, zmniejsza stopień ujemnej oceny, przez co obniża natężenie jego winy"15. W tym stanie rzeczy możliwość wyjścia powyżej górnej granicy ustawowego zagrożenia karą jawi się więc nie tylko jako rozwiązanie nieracjonalne, ale także niesprawiedliwe.

Uznając zasadność niektórych spośród przytoczonych powodów rezygnacji z możliwości nadzwyczajnego obostrzenia kary za czyn ciągły, nie można nie zauważyć pewnych niekonsekwencji i mankamentów tego rozwiązania. Odnosząc się do pierwszego z argumentów, zgodzić należy się z K. Daszkiewicz, która kwestionując status quo w zakresie wymiaru kary za czyn ciągły, zwraca uwagę, iż konstrukcja ta odnosi się nie tylko do ,zachowań”, które oceniane z osobna nie stanowią przestępstw, stając się nimi dopiero wraz z całościową ich oceną, ale także ,zachowań”, które — gdy oceniać je w oderwaniu od siebie — są takimi samymi przestępstwami jak te, które tworzą ciąg przestępstw. Nie zawsze też w przypadku wielości zachowań traktowanych sumarycznie ekwiwalentem nadzwyczajnego obostrzenia będzie przejście na typ kwalifikowany przewidujący surowszą odpowiedzialność karną ${ }^{16}$. W tych więc przypadkach, gdy określony typ przestępstwa nie przewiduje odmiany kwalifikowanej sty-

14 M. Cieślak, Polskie prawo karne. Zarys systemowego ujęcia, Warszawa 1994, s. 397.

15 A. Sadowski, Przestepstwo ciagłe, Lublin 1949, s. 37, za: W. Zalewski, Przestepstwo ciagłe de lege lata $i$ de lege ferenda, „Prokuratura i Prawo” 2003, nr 4, s. 78.

16 K. Daszkiewicz, op. cit., s. 23-24.

Nowa Kodyfikacja Prawa Karnego 46, 2017

(C) for this edition by CNS 
pizowanej na podstawie znamienia ilościowego (kwantytatywnego) a te stanowią przecież absolutną większość w ustawie karnej — wielość zachowań (czynów) tworzących przestępstwo ciągłe może nie znaleźć właściwego odzwierciedlenia w indywidualnokonkretnym wymiarze kary, rodząc nieodparte wrażenie częściowej bezkarności sprawcy ${ }^{17}$.

Ten kierunek krytyki wspiera dodatkowo to, że w ramach czynu ciągłego mogą być realizowane także bardzo poważne przestępstwa, w tym zbrodnie. Traktowanie wielości zbrodni, gdy wynikają one z tożsamego zamiaru, jako „zbrodni ciągłej”, na którą jedyną reakcją jest jedna kara mieszcząca się w granicach jej zwyczajnego wymiaru, z perspektywy realizacji dyrektywy sprawiedliwościowej, musi budzić zastrzeżenia. Wymóg tożsamości osoby pokrzywdzonego w przypadku zamachów na dobra osobiste w pewnym stopniu te obawy redukuje, ale ich nie dezaktualizuje $^{18}$. Brak możliwości nadzwyczajnego, a nawet ustawowo zadekretowanego zwyczajnego obostrzenia kary, gdy czyn ciągły traktowany byłby jako okoliczność obciążająca ${ }^{19}$, wywołuje zatem stan zauważalnej asymetrii w relacji między konsekwencjami art. $12 \mathrm{k} . \mathrm{k}$. a następstwami zbiegu z art. $91 \S 1$ k.k. Sekwencyjność (seryjność, powtarzalność) jako okoliczność, która zwiększa naganność zachowań sprawcy, właściwa jest przecież nie tylko ciągowi przestępstw, ale i czynowi ciągłemu. Analogiczne, krytyczne stanowisko wobec pominięcia w ustawie możliwości nadzwyczajnego obostrzenia kary wobec sprawcy czynu ciągłego zajmuje A. Michalska-Warias. Uzasadnia je sugestywnym przypadkiem zupełnie nieuprawnionego uprzywilejowania w traktowaniu sprawców kilkukrot-

17 Ibidem; K. Daszkiewicz, Nadzwyczajne obostrzenie kary, [w:] Nowa kodyfikacja karna. Kodeks karny. Krótkie komentarze..., s. 84.

18 Trafnie omawiany niedostatek regulacji art. 12 k.k. ilustruje Ł. Pohl, podając przykład mężczyzny, który w zamiarze z góry powziętym, w krótkich odstępach czasu, dopuszcza się zgwałcenia swojej małżonki. W takim przypadku brak możliwości modyfikacji granic odpowiedzialności karnej na podobieństwo skutków ciągu przestępstw razi swą niesprawiedliwością — Ł. Pohl, [w:] Kodeks karny. Komentarz, red. R.A. Stefański, Warszawa 2015, s. 191.

19 Wypada wspomnieć, iż analogiczne rozwiązanie zawierał kodeks z 1969 r. odnośnie do powrotności do przestępstwa. Recydywa specjalna stanowiła w nim podstawę nadzwyczajnego obostrzenia kary (art. 60 k.k.), natomiast recydywa ogólna z art. 52 k.k. okoliczność obciążającą, obostrzającą karę ,zwyczajnie”, a więc w granicach ustawowego zagrożenia.

Nowa Kodyfikacja Prawa Karnego 46, 2017

(C) for this edition by CNS 
nego pobicia tej samej osoby w warunkach zamiaru z góry powziętego (art. $158 \S 1$ k.k. w zw. z art. 12 k.k.) w stosunku do takiego samego pobicia kilku osób w zamiarze każdorazowo odtwarzanym, podejmowanym sukcesywnie. W pierwszym przypadku, pomimo istnienia pewnej trwałości złego postanowienia, wynikającej z przyjęcia ,z góry powziętego zamiaru" wielokrotnej realizacji znamion czynu zabronionego, sprawcy odpowiadaliby do 3 lat kary pozbawienia wolności, w drugim natomiast, za sprawą reguły progresji karania określonej w art. $91 \S 1$ k.k. — do 4 lat i 6 miesięcy. Trudno takie rozwiązanie uznać nie tylko za racjonalne, ale i sprawiedliwe, choćby z punktu widzenia konstytucyjnej zasady równości ${ }^{20}$.

W tym kontekście zwrócić należy uwagę, iż tak znaczna dyferencjacja na poziomie wymiaru kary obu instytucji opiera się o niezwykle niepewną — nie tylko na płaszczyźnie wykładniczej, ale także od strony dowodowej — przesłankę ,,z góry powziętego zamiaru”. W sytuacji więc, w której sprawca dopuści się kilku przestępstw spełniających wszystkie warunki ciągu i gdy dodatkowo ziści się lub zostanie jedynie uprawdopodobniony warunek subiektywny wynikający z art. 12 k.k., konieczne stanie się przyjęcie konstrukcji czynu ciągłego, która istotnie uprzywilejowuje sytuację sprawcy. Nie można bowiem tracić z pola widzenia tego, iż przesłanka „zamiaru z góry powziętego" musi być przyjęta nie tylko wówczas, gdy sąd na podstawie materiału dowodowego odnoszącego się do całokształtu okoliczności przedmiotowych i podmiotowych nie ma wątpliwości co do jego istnienia, ale — zgodnie z zasadą in dubio pro reo — także w tych przypadkach, w których takie wątpliwości się zrodzą, gdy jednak sprawca konsekwentnie będzie utrzymywał, iż działał „na raty”, fakt ten jedynie uprawdopodabniając. Kontrdowód na brak takiego zamiaru, wobec powszechnie znanych trudności towarzyszących dowodzeniu treści strony podmiotowej, może być nie tylko utrudniony, ale nawet niemożliwy do przeprowadzenia. Wątpliwości te muszą być więc ostatecznie uwzględniane na korzyść sprawcy. Konstrukcja czynu ciągłego w obowiązującym ujęciu niewątpliwie taką właśnie korzystniejszą sytuację po stronie spraw-

20 Por. A. Michalska-Warias, Niektóre problemy przestępstwa ciagłego i tzw. ciagu przestęstw w rozumieniu art. 12 k.k. i art. 91 k.k., „Annales Universitatis Mariae Curie-Skłodowska. Sectio G. Ius” 2000, 47, s. 216.

Nowa Kodyfikacja Prawa Karnego 46, 2017

(C) for this edition by CNS 
cy tworzy. W tym stanie rzeczy, w rzeczywistości procesowej, kreatywna co do treści strony podmiotowej linia obrony sprawcy kilku przestępstw jest zatem nie tylko bardzo prawdopodobna, ale w razie profesjonalnej pomocy prawnej i minimum okoliczności faktycznych, wskazujących na możliwość istnienia zamiaru z góry powziętego, niemal pewna.

Odnosząc się do argumentu, który rezygnację z możliwości nadzwyczajnego obostrzenia kary w stosunku do czynu ciągłego wiąże z podobieństwem do tzw. przestępstw zbiorowych, za które sprawca odpowiada przecież w granicach zwyczajnego, a nie nadzwyczajnego wymiaru kary, należy stwierdzić, iż ustawowa rzeczywistość przedstawia się dokładnie odwrotnie. Argumentacja tego stanowiska zdaje się nie uwzględniać ustawowego faktu, iż powtarzalność (wielokrotność, ciągłość) zachowań składających się na znamię czasownikowe przestępstw zbiorowych (wieloczynnościowych) zwiększająca stopień ich społecznej szkodliwości znajduje właśnie swoje odzwierciedlenie, wprawdzie nie w nadzwyczajnym wymiarze kary, ale w ustawowym zagrożeniu karą przewidzianą za tę kategorię przestępstw. Można się o tym przekonać, porównując chociażby granice zagrożenia karą za znieważenie (art. 216 § 1 k.k. — kara grzywny albo ograniczenia wolności), naruszenie nietykalności cielesnej (art. $217 \S 1$ k.k. - kara grzywny, ograniczenia wolności albo pozbawienia wolności do roku) czy lekki uszczerbek na zdrowiu (art. 157 § 2 k.k. kara grzywny, ograniczenia wolności albo pozbawienia wolności do lat 2), realizowane jako pojedyncze zachowania, z zagrożeniem przewidzianym za przestępstwo znęcania się (art. $207 \S 1$ k.k. — kara pozbawienia wolności od 3 miesięcy do 5 lat, a w odniesieniu do typów kwalifikowanych z $§ 2$ lub 3 - odpowiednio: do 10, a nawet 12 lat pozbawienia wolności), którego znamię czasownikowe realizują wszakże powtarzalne zachowania, które brane pod uwagę z osobna mogą wyczerpywać znamiona wymienionych przestępstw. Trudno więc zgodzić się z opinią, iż ustawodawca określając granice odpowiedzialności karnej, nie różnicuje oceny zachowań pojedynczych i zbioru tych zachowań w sankcji, co innego bowiem wynika z porównania granic ustawowego zagrożenia przewidzianego za jednokrotne i wielokrotne naruszenie określonej normy sankcjonowanej. Stosując więc analogiczne rozumowanie, przyjęcie możliwości nadzwyczajnego obostrzenia kary za czyn ciągły z art. 12 k.k. uznać należałoby nie tylko za rozwiązanie z tej perspektywy w pełni konsekwentne, wpisu- 
jące się w ogólniejszy obraz gradacji karalności zachowań jednokrotnych i wielokrotnych, ale i całkowicie racjonalne z punktu widzenia realizacji polityki karnej, pozwalające na możliwość surowszego potraktowania sprawcy w przypadkach, których sumaryczna ocena tego by wymagała, a co tylko w odniesieniu do nielicznych typów czynów zabronionych — operujących ilościowym znamieniem skutku — jest możliwe, gdy znajduje wyraz w surowszym zagrożeniu karą przewidzianym za typ kwalifikowany.

Trudno także podzielić przywołany wcześniej pogląd M. Cieślaka, kwestionujący, co do zasady, potrzebę nadzwyczajnego wymiaru kary za przestępstwo ciągłe. Przyznać trzeba, iż wątpliwość ta jest w pełni zasadna w odniesieniu do tej części przypadków wielości zachowań tworzących przestępstwo ciągłe, w której czyny (zachowania) jednostkowe, brane pod uwagę każdy z osobna, nie realizują znamion typu czynu zabronionego, a dopiero zsumowanie ich następstw pozwala na przypisanie sprawcy przestępstw, jak i tych, których połączone skutki realizują już znamiona typu kwalifikowanego. Jeżeli jednak w skład przestępstwa ciągłego wchodzą przestępstwa, w tym ciężkie, które pozostają poza kręgiem zachowań przywołanych wyżej, możliwość wymierzenia sprawcy kary w takich samych granicach, jak w przypadku dopuszczenia się jednego tylko czynu, tworzy nieodparte wrażenie bezkarności pozostałych zachowań objętych konstrukcją art. 12 k.k. W tej sytuacji nie tylko względy kryminalnopolityczne, ale także ustawowa powinność uwzględnienia przy wymiarze kary ogólnych dyrektyw, zwłaszcza zaś dyrektywy sprawiedliwościowej, wskazywałaby na potrzebę dania sądowi choćby możliwości uadekwatnienia dolegliwości karnej, gdy górna granica zagrożenia karą przewidziana za przestępstwo, którego znamiona sprawca wielokrotnie wyczerpał, okaże się z tej perspektywy niewystarczająca.

Odnosząc się wreszcie do argumentu podmiotowego negującego potrzebę nadzwyczajnego wymiaru kary za przestępstwo ciągłe, za czym miałoby jakoby przemawiać usprawiedliwiające postawę sprawcy „stępienie jego wrażliwości moralnej” wskutek wielokrotnej realizacji znamion czynu zabronionego, w konsekwencji umniejszające jego winę, należy stwierdzić, iż w optyce tej zgadza się jedynie przyjęta wstępna teza zakładająca „stępienie wrażliwości” sprawcy. Jako logicznie i kryminalno- 
politycznie niepoprawne ocenić należy natomiast wnioskowanie w takiej sytuacji o potrzebie łagodności ustawy. Powtarzalny brak respektu dla normy prawnej nie może być bowiem usprawiedliwiany. Zobojętnienie sprawcy wobec zakazu karnego, zwłaszcza gdy jego źródłem jest powtarzalność zabronionych przez ustawę zachowań, w żadnym razie nie może być traktowane ani jako okoliczność redukująca, ani nawet stabilizująca zakres odpowiedzialności karnej. Stępiona wrażliwość sprawcy wymaga bowiem raczej jej „wyostrzenia”, w tym przy użyciu racjonalnie surowej represji karnej, niż pobłażliwości uzasadnianej rzekomo niższym stopniem zawinienia.

Jedynie na marginesie wypada dodać, iż w kontekście pominięcia możliwości nadzwyczajnego obostrzenia kary za czyn ciągły wszelkiej mocy przekonywania odmówić należy formułowanemu czasami w piśmiennictwie argumentowi „statystycznemu”, iż pod rządami poprzednio obowiązującej regulacji (art. 58 k.k. z 1969 r.) sądy z możliwości nadzwyczajnego obostrzenia kary korzystały jedynie sporadycznie, toteż rezygnacja z niego w obowiązującej ustawie jest kryminalnopolitycznie usprawiedliwiona. Jak słusznie zauważa K. Daszkiewicz, jest to wnioskowanie całkowicie niepoprawne już choćby z tej racji, iż określoną politykę karną realizuje się nie tylko przy pomocy kar wymierzanych i wykonywanych, ale także grożących. To one wszakże stanowią w tej polityce punkt wyjścia, aktualizując się, zanim jeszcze do naruszenia normy prawnej dojdzie, a więc $\mathrm{w}$ momencie, $\mathrm{z}$ perspektywy funkcji ochronnej prawa karnego, najlepszym. Brak możliwości nadzwyczajnego obostrzenia w przypadku czynu ciągłego z tego akurat punktu widzenia stanowi więc bezspornie rozwiązanie niewłaściwe ${ }^{21}$. Jednocześnie, jak wiadomo, wspomniany argument nie przemówił również do ustawodawcy, który w zakresie następstw ciągu przestępstw, także będącego przecież pochodną przestępstwa ciągłego, wybrał inną drogę. W kontekście poczynionych uwag wydaje się, iż w zakresie dyrektywy wymiaru kary za czyn ciągły i ciąg przestępstw drogi te nie powinny były się rozejść.

21 Por. K. Daszkiewicz, Kary za przestępstwa ciagłe i ciagi przestępstw..., s. 23-24 oraz 26; eadem, Przestępstwo ciagłe i ciag przestęstw, „Prokuratura i Prawo” 1997, nr 11, s. 8-9; eadem, Nadzwyczajne obostrzenie kary..., s. 84-85 i 87-88; W. Zalewski, op. cit., s. 84 . 


\section{The remarks on the legal character of the directive of the punishment for the series of crimes}

\section{Summary}

The article considers the problem of punishment for the series of crimes. It raises the legal character of the rule of tightening the criminal responsibility as a consequence of committing crimes remaining in a confluence of events connected with the buckle of continuity. The main doubt accompanying such evaluation is connected with the answer to the question if the legal effects within the scope of punishment resulting from the art. $91 \S 1$ of the Penal Code express ordinary or extraordinary punishment. The dispute about the legal nature of the consequences resulting from that regulation has not only the theoretical-legal dimension. Accepting one of those options causes far-reaching legal consequences within the sphere of the law practice application. It decides about the scope of the legal responsibility and determines the relations with other statutory premises that modify its limits. In this context there are also the remarks considering the conditions of accepting the set of principles, resulting from art. 57 of the Penal Code, reforming those limits with the rule of punishment for the series of crimes. The analysis takes up the problem of the punishment for the continuous act defined in art. 12 of the Penal Code. We have to take into consideration that this institution derives from the same as the series of crimes structure of the continuous act of crime that was in the Penal Code from 1969, which is the basis of the extraordinary tightening the punishment. Thus there comes the question - whether resigning from modifying the principles of legal responsibility for the continuous act of crime can lead to impression of the dissymmetry of penalty of both structures, and is that the reasonable and rational solution.

Keywords: series, confluence of events, tightening, crime, punishment, scope, extraordinary, responsibility, multiplicity, continuity, modification, directive. 